\title{
Porcine Blood and Liver as Sporadic Sources of Hepatitis E Virus (HEV) in the Production Chain of Offal-Derived Foodstuffs in Poland
}

\author{
E. Bigoraj ${ }^{1}$-W. Paszkiewicz ${ }^{2}$ (D) A. Rzeżutka ${ }^{1}$ (i)
}

Received: 8 October 2020 / Accepted: 9 April 2021 / Published online: 23 April 2021

(c) The Author(s) 2021

\begin{abstract}
Pig's blood and liver are valuable edible slaughter by-products which are also the major ingredients of offal-derived foodstuffs. The aim of the study was an evaluation of the occurrence of hepatitis E virus (HEV) and porcine adenovirus (pAdV) as an index virus of faecal contamination in pig's blood and liver for human consumption. In total, 246 samples of retail liver $(n=100)$ and pooled pig's blood $(n=146)$ were analysed for the presence of HEV and pAdV. Blood samples were individually collected from 1432 pigs at slaughter age. Viral genomic material, including RNA of a sample process control virus was isolated from food samples using a QIAamp ${ }^{\circledR}$ Viral RNA Mini Kit. Virus-specific IAC-controlled real-time PCR methods were used for detection of target viruses. HEV RNA was found in $6(2.4 \%$; 95\% CI: $0.9-5.2)$ out of 246 samples of tested foodstuffs. The virus was detected in pig's blood (3.4\%; 95\% CI: $1.1-7.8)$ and liver $(1.0 \%$; 95\% CI: $0.0-5.0)$ with no significant differences observed in the frequency of its occurrence between the two by-products $(t=1.33 ; p=0.182>0.05)$; however PAdV was detected more frequently in pig's blood than in liver $(t=4.65 ; p=0.000<0.05)$. The HEV strains belonged to the $3 \mathrm{f}$ and $3 \mathrm{e}$ subtype groups and the pAdV strains were assigned to serotype 5 . PAdV was detected in pigs regardless of the farm size from which they originated. The number of animals raised on the farm (the farm size) had no influence on the occurrence of HEV or pAdV infections in pigs $(F=0.81, p=0.447>0.05$ for HEV; $F=0.42, p=0.655>0.05$ for pAdV). Although HEV was detected in pig's offal only sporadically, consumers cannot treat its occurrence with disregard as it demonstrates that HEV-contaminated pig tissues can enter the food chain.
\end{abstract}

Keywords Hepatitis E virus · Porcine adenovirus · Detection · Blood for human consumption · Pig's liver

\section{Introduction}

Foodborne transmission of hepatitis E virus (HEV) to humans was described for the first time in 2003 and infection was linked to consumption of raw deer meat (Tei et al., 2003). In the subsequent years, cases of HEV infections were linked with ingestion of pig liver-derived foodstuffs (Colson et al., 2010; Kubacki et al., 2017; Renou et al., 2014; Yapa et al., 2016), undercooked pig's liver (Guillois et al., 2016; Miyashita et al., 2012; Yapa et al., 2016; Yazaki et al., 2003),

A. Rzeżutka arzez@ piwet.pulawy.pl

1 Department of Food and Environmental Virology, National Veterinary Research Institute, Al. Partyzantów 57, 24-100 Puławy, Poland

2 Department of Food Hygiene of Animal Origin, Faculty of Veterinary Medicine, University of Life Sciences in Lublin, ul. Akademicka 12, 20-950 Lublin, Poland pork (Miyashita et al., 2012) and the liver and meat of wild boars (Masuda et al., 2005; Matsuda et al., 2003; Tamada et al., 2004). Other routes of infections are consumption of contaminated water (King et al., 2020), blood transfusion (Boxall et al., 2006; Matsubayashi et al., 2004; Mitsui et al., 2004; Satake et al., 2017), organ transplantation (Kamar et al., 2008) and likely through vertical transmission from infected mother to foetus (Anty et al., 2012).

Annually, 20 million new HEV infections in humans are recorded worldwide, and in over three million individuals the infection results in acute hepatitis, while about 44 thousand affected persons die (WHO, 2019). In Europe, between 2005 and 2015, a ten-fold increase in the number of HEV infections in humans has been observed, most of which could result from foodborne transmission (ECDC, 2017). Disease in humans is caused by HEV strains classified to gt 1-4 (Milojević et al., 2019; Pérez-Gracia et al., 2015; Smith et al., 2014; WHO, 2020; Yugo et al., 2013) with 23 subtypes (3a-m, ra, 4a-i) described so far (Smith 
et al., 2020). Besides humans gt 3 and 4 virus strains can also infect several species of farm animals and wildlife (Smith et al., 2014; WHO, 2020; Milojević et al., 2019). It is noteworthy that the presence of anti-HEV antibodies was found more often in people eating pork liver sausage, pâté and wild boar meat (Mansuy et al., 2016). This is a consequence of the presence of the virus in tissues of asymptomatically infected animals entering the food chain, instances of which are the detection of HEV RNA in muscles (Di Bartolo et al., 2012; Garcia et al., 2020; Intharasongkroh et al., 2016), liver (Boxman et al., 2019; Feurer et al., 2018; Garcia et al., 2020), kidney and heart (Garcia et al., 2020) as well as in pig's blood (Boxman et al., 2017; Geng et al., 2019). Food law regulations define pig's blood and liver as meat, classifying them as offal (Regulation (EC) No. 853/2004). They are valuable edible slaughter by-products suitable for human consumption (Banach et al., 2011). Edible blood (in Poland obtained only from pigs and cattle) should be collected according to specific sanitary provisions and meet sensory, physicochemical and microbiological requirements. They include the absence of pathogenic microorganisms, in particular Salmonella spp., coagulase-positive staphylococci, Clostridium botulinum, Clostridium perfringens and Erysipelothrix rhusiopathiae (Polish Standard PN-A-85701, 1964). For pig's livers, the detailed organoleptic standards, the requirements for their examination, packaging and storage and the microbial recommendations are specified elsewhere (Polish Standard PN-A-82000, 1965, Polish Standard PN-A-82004, 1986, Regulation (EC) No. 853/2004, 2004, ICSMF, 1986; ICSMF, 2011).

The aim of the study was an evaluation of the occurrence of HEV and pAdV (the latter as an index virus of pig faecal contamination) in edible pig's blood and liver used for production of offal-derived foodstuffs. In addition, virus prevalence in these food ingredients was analysed considering the size of the farm which slaughtered animals originated from, farm husbandry and feeding systems.

\section{Materials and Methods}

\section{Sample Process Control Virus (SPCV)}

Feline calicivirus (FCV) with a titre of $10^{7.1} \mathrm{TCID}_{50} / \mathrm{ml}$ was used as a sample process control virus (SPCV) added to liver and blood samples before analysis. It belongs to the virus collection of the Department of Food and Environmental Virology at the National Veterinary Research Institute in Poland. Preparation of the virus suspension in cell culture was previously described by Rzeżutka et al. (2008).

\section{Samples of Edible Blood and Liver}

In total, 246 samples of liver $(n=100)$ and pooled pig's blood $(n=146)$ were analysed for the presence of HEV and pAdV. The liver was purchased through regular retailers and originated from different production batches which were sold during the years 2016-2017, while the blood was collected during multiple visits to two slaughterhouses during 2018 and 2019. The blood came from animals aged from 3 months (porkers) to 24 months (backfatter sows). Finishers aged 5-6 months constituted $99.7 \%$ of the sampled pigs. The animals came from farms of different sizes breeding fewer than 25 pigs in the case of the small farms, between 25 and 50 pigs if the breeder was medium-sized and more than 50 for the large operations. Farms were located in Mazovia, Kujawy-Pomerania, Lubelskie, Łódzkie and Podlaskie, which are central and eastern voivodeships of Poland. Characteristics of the farms and husbandry details in relation to the age and weight of slaughtered pigs and the scheme of sampling are presented in Table 1. From each slaughter batch of pigs representing a particular farm, 10 randomly selected animals were sampled. However, the number of collected blood samples depended on the number of pigs raised on the particular farm. In the case of the small farms, a single sample of pooled blood per farm was prepared for analysis consisting of individual blood samples obtained from 10 pigs raised there, with the exception of

Table 1 Characteristics of animal farms, number of slaughtered pigs and collected blood samples

\begin{tabular}{|c|c|c|c|c|c|c|c|c|}
\hline \multirow[t]{2}{*}{ Farm size } & \multicolumn{3}{|l|}{ Pig } & \multirow[t]{2}{*}{ Feeding type } & \multirow[t]{2}{*}{ Housing system } & \multirow[t]{2}{*}{ No. of farms } & \multirow{2}{*}{$\begin{array}{l}\text { No. of pooled } \\
\text { blood samples }\end{array}$} & \multirow{2}{*}{$\begin{array}{l}\text { No. of animals per } \\
\text { slaughter batch } \\
\text { (Median) }\end{array}$} \\
\hline & Age (months) & Weight (kg) & Origin & & & & & \\
\hline Small & $3-24$ & $35-300$ & Own breeding & Own feed & Straw bedding & 21 & 21 & $5-13(9)$ \\
\hline Medium & $5-24$ & $100-200$ & Own breeding & Own feed & Straw bedding & 7 & 14 & $16-24(20)$ \\
\hline \multirow[t]{4}{*}{ Large } & $5-6$ & $105-140$ & Own breeding & Own feed & $\begin{array}{c}\text { Straw bedding, } \\
\text { Slatted floor }\end{array}$ & 7 & 21 & $25-139(50)$ \\
\hline & & & & Commercial feed & & 14 & 42 & $30-166(55)$ \\
\hline & & & Import & Own feed & $\begin{array}{c}\text { Straw bedding, } \\
\text { Slatted floor }\end{array}$ & 4 & 12 & $168-270(172)$ \\
\hline & & & & Commercial feed & & 12 & 36 & $39-660(168)$ \\
\hline
\end{tabular}


nine small farms where the number of kept pigs was less than 10 and the pooled sample consisted of blood collected from between 5 and 9 slaughtered animals. At least eight individual pigs' blood samples were included in three pools representing medium farms. If the animals originated from the medium-sized or large farms then two and three pooled samples were analysed respectively. With this scheme, sampling resulted in collection of blood from 1432 pigs. Briefly, an individual blood sample of $\sim 50 \mathrm{ml}$ was collected from an incision of the major blood vessels in the neck and thoracic inlet. Blood samples were pooled without using an anticoagulant and then a tested portion of the blood of no less than $40 \mathrm{ml}$ was prepared. Samples were frozen at $-20^{\circ}$ $\mathrm{C}$ until use. The slaughter of the animals respected the EU animal protection legislation (Council Regulation (EC) No. 1099/2009).

Samples of pig's liver $(\sim 100 \mathrm{~g})$ were purchased from two local butcher's shops in Puławy, Poland selling an assortment of meats. They were supplied with pig's liver by slaughterhouses operating in Lubelskie province. Throughout the sampling period, each shop was visited at least twice a month. The peripheral part of the right liver lobe (lobus hepatis dexter) or caudate lobe (lobus hepatitis caudatus) was sampled. Samples were frozen at $-20^{\circ} \mathrm{C}$ until use.

\section{Isolation of Viral RNA and Estimation of SPCV Recovery from Liver Samples}

A $2 \mathrm{~g}$ pieces of pig's liver were cut from defrosted organs and placed to sterile $50 \mathrm{ml}$ falcon tubes. Subsequently, FCV inoculum $(10 \mu \mathrm{l})$ was directly placed on the sample. After virus adsorption a $1 \mathrm{ml}$ of PBS was added followed by a mechanical tissue disruption (Omni TH 220-PCRH, Omni International, USA). The obtained homogenate was centrifuged at $14,000 \times g$ for $5 \mathrm{~min}$. at $2-8{ }^{\circ} \mathrm{C}$. Isolation of viral RNA from $100 \mu \mathrm{l}$ of liver homogenate or frozen whole blood was performed using the QIAamp® Viral RNA Mini Kit (Qiagen, Germany) according to the manufacturer's instructions. Nucleic acids were suspended in RNA- and DNA-free water in a final volume of $100 \mu$ l. RNA was directly used for testing or stored at $-80^{\circ} \mathrm{C}$. To confirm correct sample processing and assess the efficiency of virus recovery from each analysed liver and blood sample, an SPCV was used. The virus recovery was assessed based on a comparison of the $\mathrm{Cq}$ (quantification cycle) values obtained for the SPCV after sample processing with those generated for isolated viral RNA derived from the virus inoculum used for sample spiking (Diez-Valcarce et al., 2012). The results of virus extraction efficiency were classified as poor (extraction efficiency $<1 \%)$, acceptable (1-10\%), good ( $>10-50 \%)$ and very good $(>50 \%)$. In addition to the SPCV, a negative control was included (reagents were used for nucleic acid isolation and water in the place of the tested sample).

\section{Virus Detection and Identification of HEV Subtypes and pAdV Serotypes}

Detection of HEV and FCV RNAs was conducted using respectively a duplex real-time RT-qPCR (Maunula et al., 2013) containing an internal amplification control (IAC) (Diez-Valcarce et al., 2011) and a real-time RTPCR (Lowther et al., 2008). Detection of pAdV DNA was also performed by the real-time PCR method (Maunula et al., 2013). For amplification of virus nucleic acids an UltraSense $^{\mathrm{TM}}$ One-Step Quantitative RT-PCR kit (Invitrogen) and a TaqMan Universal PCR Master Mix (Applied Biosystems) were employed. The reactions were conducted according to the protocols previously described (Bigoraj et al., 2020; Maunula et al., 2013). A positive reaction control consisting of plasmid DNA (pCR2.1 TOPO-rSTD) with an insertion of a cDNA (HEV) or DNA (pAdV) fragments was set up for each batch of tested samples (Martínez-Martínez et al., 2011). A reaction mixture containing water instead of the tested sample served as the negative control. The number of viral genome copies (G.C.) present in liver and blood samples was determined based on a standard curve prepared using a transcript serially diluted from $10^{1}$ to $10^{5}$ G.C./ $\mu$ of HEV RNA of known concentration. It was obtained during transcription of the plasmid DNA (pDrive Cloning Vector) containing a $70 \mathrm{bp}$ fragment of the ORF3 genome of HEV gt3 pig strain. The HEV genome copy number present in samples was determined by HEV RT-qPCR in duplicate reactions (Kozyra et al., 2020).

For identification of the HEV subtype or pAdV serotype of detected virus strains in edible blood and liver the ORF2 fragment (Huang et al., 2002) and fragment of the virus protein hexon gene (Wyn-Jones et al., 2011) were amplified, respectively. The resulting amplification products were separated on agarose gel and subsequently purified using the QIAquick ${ }^{\circledR}$ Gel Extraction Kit (Qiagen, Germany) according to the manufacturer's instructions. DNA fragments were sequenced and the sequences were assembled into a consensus sequence (contig) using the Chromas program (Technelysium Pty Ltd, Australia) and analyzed using the HEV Genotyping Tool (http://www.rivm.nl/mpf/typingtool/hev). The identification of pAdV serotypes was performed based on their sequence alignment with the reference sequences of human and animal adenoviruses representing different serotypes available in GenBank. Analyses were performed using BLAST (https://blast.ncbi.nlm.nih.gov/Blast.cgi).

\section{Statistical Analysis}

The presence of statistical differences in the frequency of HEV and pAdV detection in liver and blood samples was assessed by Student's $t$-test for independent pairs with previously-tested homogeneity of variance using the $\mathrm{F}$ test. 
Analysis of variance with confidence intervals (LSD) was used to assess the differences in frequency in occurrence of the viruses in tissues (liver and blood samples) of slaughtered animals originating from small, medium and large farms. Calculations were made with Statgraphics Centurion version XV (Statgraphics Technologies, USA).

\section{Results}

\section{Virus Detection in Blood and Liver}

HEV RNA was found in $6(2.4 \%$; $95 \%$ CI: $0.9-5.2 \%)$ out of 246 samples of tested foodstuffs. All blood samples showed a $100 \%$ (very good) extraction efficiency. In the case of livers the mean extraction efficiency was good $(24.07 \pm 30.15 \%)$ with values ranging from 1.1 to $100 \%$. None of the samples showed poor virus recovery. Virus was detected in five samples of pig's blood $(3.4 \% ; 95 \%$ CI: $1.1-7.8 \%)$ and in only one liver sample (1.0\%; 95\% CI: 0.0-5.0\%) (Table 2). There were no significant differences observed in the frequency of HEV occurrence between blood and liver samples $(t=1.33$; $p=0.182>0.05)$. The viral load in blood ranged from 11 G.C./ml to $9.0 \times 10^{4}$ G.C. $/ \mathrm{ml}$, whereas in liver it was as low as 16 G.C./g. PAdV was detected more frequently in pig blood than in liver $(t=4.65 ; p=0.000<0.05)$ with an overall $13 \%$ (95\% CI: 8.0-19.5\%) prevalence among the tested samples (Table 2). Only finishers raised on large farms were HEV-positive: all 5 pooled blood samples $(4.5 \%$; $95 \% \mathrm{CI}$ : $1.4-10.2 \%$ ) containing viral RNA came from among the 111 such operations (Table 3 ). The geographical distribution of the sampled farms from which pooled blood yielded HEV was Mazovia, with two samples; Kujawy-Pomerania, with two samples; and Podlaskie with one sample. PAdV was detected in pigs regardless of the farm size from which they originated. Consequently, there were 2 (14.3; CI 1.7-42.8) pAdV-positive samples of pooled blood taken from animals representing medium-sized farms, 4 (19.0; CI 5.4-41.9) from small and 13 (11.7; CI 6.3-19.2) from large farms (Table 3). The number of animals raised on the farm (the farm size) had no influence on the occurrence of $\mathrm{HEV}$ or pAdV infections in pigs $(F=0.81, p=0.447>0.05$ for $\mathrm{HEV}$; $F=0.42, p=0.655>0.05$ for $\mathrm{pAdV})$.

A specific PCR product corresponding to the HEV ORF 2 region was obtained for five virus strains. Four strains belonged to the $3 \mathrm{f}$ virus subtype (previously designated 31 (p) subtype, EU360977, bootstrap value $>84 \%$ ), and one to the 3e subtype (previously undesignated, AB248521, bootstrap value 91\%) (Smith et al., 2020). HEV ORF2 sequences were deposited in GenBank under the accession numbers MT773598-MT773600 and MT780502. Nucleotide sequences of the hexon capsid protein of all pAdV strains belonged to serotype 5 (98.5\% sequence similarity to $\mathrm{pAdV}-5$ reference sequence AF289262) with a mutual $100 \%$ sequence similarity. A representative sequence of this pAdV-5 strain was submitted to GenBank under the accession number MT895403.

\section{Discussion}

In this study, the presence of HEV RNA was only detected in $5(3.4 \%)$ out of 146 samples of pig's blood and in one liver, which constituted a mere $1 \%$ of the tested liver samples.

Table 2 Results of detection of HEV and pAdV in pig's blood and livers

\begin{tabular}{|c|c|c|c|c|c|c|}
\hline \multirow[t]{2}{*}{ Sample type } & \multirow[t]{2}{*}{ No. of samples } & \multicolumn{3}{|l|}{$\mathrm{HEV}$} & \multicolumn{2}{|l|}{$\mathrm{pAdV}$} \\
\hline & & $\begin{array}{l}\text { No. of positive sam- } \\
\text { ples }(\% \text {; CI } 95 \%)\end{array}$ & $\mathrm{Cq} \pm \mathrm{SD}$ & Virus load (G.C./ml or g) & $\begin{array}{l}\text { No. of positive sam- } \\
\text { ples }(\% \text {; CI } 95 \%)\end{array}$ & $\mathrm{Cq} \pm \mathrm{SD}$ \\
\hline Blood & 146 & $5(3.4 ; 1.1-7.8)$ & $36.0 \pm 2.5$ & $11-9.0 \times 10^{4}$ & $19(13.0 ; 8.0-19.5)$ & $39.0 \pm 1.3$ \\
\hline Liver & 100 & $1(1.0 ; 0.0-5.0)$ & 40.7 & 16 & $0(0 ; 0-3.6)$ & - \\
\hline
\end{tabular}

Table 3 Prevalence of HEV and pAdV in pig's blood in relation to the size of the farm breeding the animals

\begin{tabular}{lclll}
\hline Farm size & No. of farms & $\begin{array}{l}\text { No. of pooled } \\
\text { blood samples* }\end{array}$ & \multicolumn{2}{l}{ No. of positive samples } \\
\cline { 4 - 5 } & & 21 & $0(0 ;$ CI $0-16.1)$ & $4(19.0 ;$ CI 5.4-41.9) \\
\hline Small & 21 & 14 & $0(0 ;$ CI $0-23.1)$ & $2(14.3 ;$ CI $1.7-42.8)$ \\
Medium & 7 & 111 & $5(4.5 ;$ CI $1.4-10.2)$ & $13(11.7 ;$ CI 6.3-19.2) \\
Large & 37 & 146 & $5(3.4 ;$ CI $1.1-7.8)$ & $19(13.0 ;$ CI $8.0-19.5)$ \\
Total & & &
\end{tabular}

*Each small-scale farm was represented by one pooled blood sample (each pooled sample consisted of blood taken from 10 pigs), the medium-scale and large-scale size farms were represented by two and three samples respectively 
There were no statistically significant differences observed between the virus' occurrence in liver samples and blood samples. HEV has also been detected in livers of locally raised pigs in Africa (de Paula et al., 2013; Temmam et al., 2013), albeit occasionally; in contrast in Europe up to $31 \%$ of retailed liver contained the virus (Feurer et al., 2018; Forgách et al., 2010). However, there were differences observed between countries. For example, $15.5 \%$ of pig livers collected at the time of animal slaughter were positive for HEV RNA (Garcia et al., 2020). Nearly three times lower $(6.3 \%)$ frequency of virus detection in slaughtered pigs was reported by Geng et al. (2019) with not significant difference in detection rates between livers collected from slaughterhouses and retail markets. When a pork production chain was analysed in the Czech Republic, Italy and Spain, a mean $4 \%$ prevalence of HEV was detected in livers collected at a slaughterhouse stage (Di Bartolo et al., 2012). Compared to the European food market, HEV was detected in pig's livers with a lower frequency in Asia (0.28-12.4\%) (Hoan et al., 2019; Intharasongkroh et al., 2016) and in North and South America (4.9-11\%) (Feagins et al., 2007; Wilhelm et al., 2014). As with pig's livers, viral RNA has also been sporadically (1.8\%) found in pig's blood, (Geng et al., 2019), and sera (6.7\%) of slaughtered animals (Garcia et al. 2020), despite the virus being highly prevalent (23.4-100\%) in blood and blood-derived by-products such as haemoglobin, fibrinogen and plasma (Boxman et al., 2017; Geng et al., 2019). Differences in virus occurrence in edible blood between studies may stem from differences observed between countries in natural virus prevalence in pigs (Berto, Backer, et al., 2012; Di Bartolo et al., 2008; Lee et al., 2020) and the age of slaughtered animals, as the likelihood of viraemia increases in younger pigs (Meng et al., 1997; Sooryanarain et al., 2020; Wu et al., 2002).

In this study HEV was more frequently detected in blood that in livers. Its sporadic detection in pork slaughter byproducts could to some extent reflect a low natural prevalence of the virus in animals at the time of slaughter. Additionally, samples of blood and liver were not collected at the same stage of the pork production chain, therefore different detection rate of HEV RNA in tested samples could be expected. Furthermore, they were also originated from different animals kept on distinct farms at different geographical locations, where HEV infections in pigs may not be frequently prevalent. This randomized sampling resulted in getting an averaged but reliable results of the HEV occurrence in tested slaughter by-products. Likewise, the discrepancy in virus detection rate between samples was not influenced by the detection method used as it was confirmed by good SPCV recovery from tested samples along with the absence of inhibition of molecular reactions.

Blood sausage and black pudding are the most popular processed offal products containing pig's blood in Europe.
Pig's blood is also added to many national dishes, for example, pig's organ soup (Malaysia and Singapore), dinuguan (Philippines), mykyrokka (Finland), tiết canh (Vietnam) or svartsoppa in Sweden. Besides whole blood, its fractions, i.e. sediment of red blood cells and plasma are also used in the meat industry (Banach \& Makara, 2011; Pełczyńska \& Libelt, 1999). Pig's liver is marketed to the consumer raw as a separate ingredient or is added to the raw or dried liver sausages sold in Europe (Colson et al., 2010; Giannini et al., 2018; Renou, 2014).

Generally meat products undergo heat treatment before consumption; nevertheless there are still some food varieties containing blood or liver which are consumed raw or subjected to thermal processing which might be insufficient to inactivate the virus (Barnaud et al., 2012; Pavio et al., 2014), whereby a food-related risk of HEV infection is likely to arise (Boxman et al., 2019; Giannini et al., 2018; Pavio et al., 2014). For example, HEV RNA has been detected in pork liver sausages sold in the UK $(9.5 \%)$ (Berto, Martelli, et al., 2012), Spain (6\%) (Di Bartolo et al., 2012), Italy (22.2\%) (Di Bartolo et al., 2015), France (29-30\%) (Pavio et al., 2014), and Germany (26\%) (Szabo et al., 2015). The virus has been found with a higher frequency $(>36 \%)$ in pork pâté and blood sausages (Heldt et al., 2016; Mykytczuk et al., 2017).

It is noteworthy that HEV strains detected in this study were identified as gt $3 \mathrm{e}$ and $3 \mathrm{f}$ subtypes. Our results are therefore consistent with previous findings in which virus strains of the same subtypes have been detected in pigs liver (Bouwknegt et al., 2007; Bouquet et al., 2011; Garcia et al., 2020), ready-to-eat food containing pigs liver (Colson et al., 2010) or other type of pork meat produce (Di Bartolo et al., 2012).

The role of these strains in foodborne HEV transmission was evidenced by the detection of the autochthonous cases of human infection in France (Bouquet et al., 2011). Nevertheless, detection of HEV RNA does not itself indicate whether infectious or non-infectious virus particles are present (Althof et al., 2019; Szabo et al., 2015). In this study, an attempt to determine the infectivity of the HEV strains detected in raw food material was not undertaken due to an insufficient number of virus particles $\left(<10^{4}\right.$ G.C./ml $)$ contaminating food items (Takahashi et al., 2012) and the lack of a cell culture system efficiently propagating wild-type virus strains (Schemmerer et al., 2019).

Among the risk factors determining the occurrence of HEV infections in pigs are the farm size and farming practices (Di Bartolo et al., 2008; Hinjoy et al., 2013; Jinshan et al., 2010; Li et al., 2009; Rutjes et al., 2014). A higher seroprevalence rate has been observed among pigs from medium-sized farms raising 30-300 animals compared to large and small farms (Hinjoy et al., 2013). It could have resulted from poorer environmental hygiene conditions on 
medium-sized farms and from differences in feeding and farm management. It has been shown that the higher frequency of HEV infections in pigs may be influenced by more than poor on-farm hygienic conditions, being also possibly caused by a later weaning age of piglets, animal housing and separation (Walachowski et al., 2014).

In this study, there were no differences observed in the frequency of virus occurrence in animal tissues which originated from herds which were different in size and geographical location. Also, the animal diet based on commercial feed or feed made on the farm and which floor system (slatted floor or straw bedding) was used had no significant impact on the frequency of infections in slaughtered animals. HEV detection being only sporadic in slaughtered pigs could mainly be associated with animal age: active infection mostly occurs in young animals, whereas the majority of pigs at the time of slaughter are virus-free (Dalton et al., 2019; Feagins et al., 2007). In addition, the similarity in virus prevalence between the farms might have resulted from strict compliance with the biosecurity measures introduced on farms to stop the spread of african swine fever virus (ASFV) in Poland. It is believed that as high a proportion as $92.8 \%$ of slaughtered animals have had contact with the virus (Grierson et al., 2015); however, viraemia was only observed in a small percentage of slaughtered pigs (de Deus et al., 2008; Grierson et al., 2015; Sooryanarain et al., 2020). The detection of HEV RNA may be associated with infection occurring close to slaughter time, if superspreaders with external faecal shedding were present in the herd (Grierson et al., 2015).

Information on the possible occurrence of enteric viruses in food can also be gained through detection of viral indicators of faecal contamination. PAdV is abundantly shed in pig faeces; therefore it has been used as an indicator for source tracking of animal faecal contamination in meat and fresh produce supply chains (Jones \& Muehlhauser, 2017; Kokkinos et al., 2017; Maunula et al., 2013; Paszkiewicz et al., 2016). In this study, corroboration for the occurrence of HEV in pig's blood and livers being sporadic also comes from the number of samples tested positive for $\mathrm{pAdV}$ being low. Virus was only found in blood and none of the tested livers yielded positive results. To reveal the origin of the detected virus strains, sequencing of pAdV-positive amplicons was undertaken. All sequenced strains were identified as pADV-C (serotype 5) which are associated with respiratory swine disease (Horak \& Leedom Larson, 2016). It is highly likely that respiratory infection may have more general course with viremia occurring more frequently. This could explain a frequent pAdV detection in pig's blood then in liver. This finding indicates that the use of pAdVs as an indicator of fecal contamination may have a limited value when an identification of virus serotype is not performed. On the other hand, regardless the detected pAdV serotype, and given the similarities in the frequency of HEV and pAdV occurrence in tissues of slaughtered animals, it could be assumed that the infection prevalence caused by these viruses will be similar and that the virus burden in the pig population in Poland is likely to be small. This may be partly explained by the effectiveness of biosafety measures introduced on the Polish farms to combat ASFV infections, which may have also significantly reduced the transmission of other pig viruses including HEV.

This study has two possible limitations: (i) related to the detection methodology used and (ii) an underestimation of the results of virus occurrence in pig's blood tested as pooled samples. The suitability of the silica-membrane-based RNA extraction method for extraction of HEV RNA from pork slaughter by-products such as pigs blood (Chelli et al., 2021; Crossan et al., 2015; Garcia et al., 2020; Thiry et al., 2014) and livers (Bouwknegt et al., 2007; Bouquet et al., 2011; Di Bartolo et al., 2012; Garcia et al., 2020) has previously been shown. The mechanical tissue disruption performed jointly with a chemical cell lysis enabled an efficient isolation of nucleic acids, as the mean value of SPCV recovery obtained for the tested samples was equal to $(69.14 \pm 42.0 \%)$. It was comparable to the recovery rate of MNV-1 $(50.3 \pm 1.83 \%)$ which served as SPCV for blood, stool, muscle and samples of internal organs collected from slaughtered pigs (Garcia et al., 2020). A sporadic detection of the virus in blood and livers may have resulted from its low natural prevalence in animals at the time of slaughter, rather than from limitations of the method. Although the sample size used for analysis is crucial for a successful virus detection that higher amount of co-extracted food-related inhibitory substances could lower sensitivity of HEV detection (Szabo et al., 2015). Nevertheless, the use of spin-column based nucleic acid extraction and purification method allowed to remove or significantly reduce an inhibitory effect of the sample improving the efficiency of nucleic acid extraction. Likewise, as previously demonstrated the assay targeting virus ORF $2 / 3$ region showed the best detection performance for HEV RNA in plasma and human blood samples. This assay in conjunction with the membrane-based RNA extraction was able to detect HEV gt3 in human blood at the concentration of 2500Ul/ $\mathrm{ml}$ (Mokhtari et al., 2013). In this study the same method employing the amplification enzyme-mix and a detection platform, however with a higher volume of sample RNA was used for virus detection in pig's blood. Nevertheless, that change seems to be beneficial for the method as it could only increase its sensitivity. Therefore, it is conceivable that method's LOD for testing of pig's blood could be at least similar as for samples of human blood.

A possible underestimation of the results of virus occurrence when pooled blood samples are tested mainly refers to samples which could contain the virus at the concentration equal to or slightly above the detection limit of the method. 
It relates to the dilution effect of the positive sample by other uncontaminated samples being in the pool. In food virology testing of pooled samples is commonly used, for example for shellfish testing (Rzeżutka \& Carducci, 2013) and this complies to the recommendations of an ISO standard for virus detection in food (Anonymous, 2019). In the case of edible blood and its by-products they have previously been successfully tested for HEV as pooled samples (Boxman et al., 2017). It is also important to emphasize that compared to studies of Boxman et al. (2017) in this study a tested portion of blood sample was representing a much higher volume of individual sample being in the pool. In contrary to food samples but similarly to other clinical specimens, viruses are homogenously distributed in blood. This feature significantly reduces the risk of getting the false-negative results when blood is tested as pooled sample.

\section{Conclusions}

This study provides valuable data on the occurrence of HEV in pig's blood and retailed pig's livers in Poland. There were no differences observed in the frequency of virus prevalence in slaughtered pigs correlating with farm size (number of animals bred) or specific farm husbandry and feeding practices. Although the virus was only sporadically detected, its occurrence still remains consequential for consumers as it demonstrates that HEV-contaminated pig tissues can enter the food chain. Of note is that they are the major food ingredients for production of the variety of edible offal meat products which may not undergo sufficient heat-treatment (if any) to inactivate the virus (Colson et al., 2010; Giannini et al., 2018; Renou, 2014). Although meat products containing blood and/or pork liver are very popular with Polish consumers, it is difficult to unequivocally show that their consumption caused any foodborne infection or food-related intoxication outbreaks. Detection of HEV in food chain-bound pig tissues supports the assumption that the risk of HEV infection related to consumption of ready-to-eat offal-derived foodstuffs exists, however it should be verified by subsequent food testing.

Acknowledgements The authors would like to thank the commercial slaughterhouses for their participation in the study.

Funding This work was funded by the KNOW (Leading National Research Centre) Scientific Consortium "Healthy Animal - Safe Food", under Ministry of Science and Higher Education decision No. 05-1/KNOW2/2015.

Data Availability Sequences determined in this study were submitted to GenBank database under the Accession Number MT773598 - MT773600, MT780502 and MT895403.

\section{Declarations}

Conflict of interest The authors have no conflicts of interest to declare that are relevant to the content of this article.

Open Access This article is licensed under a Creative Commons Attribution 4.0 International License, which permits use, sharing, adaptation, distribution and reproduction in any medium or format, as long as you give appropriate credit to the original author(s) and the source, provide a link to the Creative Commons licence, and indicate if changes were made. The images or other third party material in this article are included in the article's Creative Commons licence, unless indicated otherwise in a credit line to the material. If material is not included in the article's Creative Commons licence and your intended use is not permitted by statutory regulation or exceeds the permitted use, you will need to obtain permission directly from the copyright holder. To view a copy of this licence, visit http://creativecommons.org/licenses/by/4.0/.

\section{References}

Althof, N., Trojnar, E., Böhm, T., Burkhardt, S., Carl, A., Contzen, M., et al. (2019). Interlaboratory validation of a method for hepatitis $E$ virus RNA detection in meat and meat products. Food and Environmental Virology, 11(1), 1-8

Anonymous (2019) EN ISO 15216-2:2019. Microbiology of food and animals feed - Horizontal method for determination of hepatitis A virus and norovirus in food using real-time RT-PCR - Part 2: Method for detection. Geneva, Switzerland

Anty, R., Ollier, L., Péron, J. M., Nicand, E., Cannavo, I., Bongain, A., et al. (2012). First case report of an acute genotype 3 hepatitis E infected pregnant woman living in South-Eastern France. Journal of Clinical Virology, 54, 76-78

Banach, M., \& Makara, A. (2011). Blood and secondary products. Chemistry, 108(10), 3-20

Barnaud, E., Rogée, S., Garry, P., Rose, N., \& Pavio, N. (2012). Thermal inactivation of infectious hepatitis $\mathrm{E}$ virus in experimentally contaminated food. Applied and Environmental Microbiology, 78(15), 5153-5159

Berto, A., Backer, J. A., Mesquita, J. R., Nascimento, M. S., Banks, M., Martelli, F., et al. (2012). Prevalence and transmission of hepatitis $\mathrm{E}$ virus in domestic swine populations in different European countries. BMC Research Notes, 5, 190

Berto, A., Martelli, F., Grierson, S., \& Banks, M. (2012). Hepatitis E virus in pork food chain, United Kingdom, 2009-2010. Emerging Infectious Diseases, 18(8), 1358-1360

Bigoraj, E., Kozyra, I., Kwit, E., \& Rzeżutka, A. (2020). Detection of hepatitis $\mathrm{E}$ virus (rabbit genotype) in farmed rabbits entering the food chain. International Journal of Food Microbiology, 319, 108507

Bouquet, J., Tessé, S., Lunazzi, A., Eloit, M., Rose, N., Nicand, E., et al. (2011). Close similarity between sequences of hepatitis $E$ virus recovered from humans and swine, France, 2008-2009. Emerging Infectious Diseases, 17(11), 2018-2025

Bouwknegt, M., Lodder-Verschoor, F., van der Poel, W. H., Rutjes, S. A., \& de Roda Husman, A. M. (2007). Hepatitis E virus RNA in commercial porcine livers in The Netherlands. Journal of Food Protection, 70(12), 2889-2895

Boxall, E., Herborn, A., Kochethu, G., Pratt, G., Adams, D., Ijaz, S., et al. (2006). Transfusion-transmitted hepatitis $E$ in a 'nonhyperendemic' country. Transfusion Medicine, 16(2), 79-83

Boxman, I. L. A., Jansen, C. C. C., Hägele, G., Zwartkruis-Nahuis, A., Tijsma, A. S. L., \& Vennema, H. (2019). Monitoring of pork liver 
and meat products on the Dutch market for the presence of HEV RNA. International Journal of Food Microbiology, 2(296), 58-64

Boxman, I. L. A., Jansen, C. C. C., Hägele, G., Zwartkruis-Nahuis, A., Cremer, J., Vennema, H., et al. (2017). Porcine blood used as ingredient in meat productions may serve as a vehicle for hepatitis E virus transmission. International Journal of Food Microbiology, 18(257), 225-231

Chelli, E., Suffredini, E., De Santis, P., De Medici, D., Di Bella, S., D'Amato, S., et al. (2021). Hepatitis E virus occurrence in pigs slaughtered in Italy. Animals (Basel), 11(2), 277

Colson, P., Borentain, P., Queyriaux, B., Kaba, M., Moal, V., Gallian, P., et al. (2010). Pig liver sausage as a source of hepatitis E virus transmission to humans. The Journal of Infectious Diseases, 202(6), 825-834

Council Regulation (EC) No 1099/2009 of 24 September 2009 on the protection of animals at the time of killing - OJ L 303, 8.11.2009, p. 1. http://data.europa.eu/eli/reg/2009/1099. Accessed on 20 December 2019

Crossan, C., Grierson, S., Thomson, J., Ward, A., Nunez-Garcia, J., Banks, M., et al. (2015). Prevalence of hepatitis E virus in slaughter-age pigs in Scotland. Epidemiology and Infection, 143(10), $2237-2240$

Dalton, H. (2019). The hepatitis E virus: Pigs might fly. Cambridge Scholars Publishing.

de Deus, N., Casas, M., Peralta, B., Nofrarías, M., Pina, S., Martín, M., et al. (2008). Hepatitis E virus infection dynamics and organic distribution in naturally infected pigs in a farrow-to-finish farm. Veterinary Microbiology, 132(1-2), 19-28

de Paula, V. S., Wiele, M., Mbunkah, A. H., Daniel, A. M., Kingsley, M. T., \& Schmidt-Chanasit, J. (2013). Hepatitis E virus genotype 3 strains in domestic pigs, Cameroon. Emerging Infectious Diseases, 19(4), 666-668

Di Bartolo, I., Angeloni, G., Ponterio, E., Ostanello, F., \& Ruggeri, F. M. (2015). Detection of hepatitis E virus in pork liver sausages. International Journal of Food Microbiology, 193, 29-33

Di Bartolo, I., Diez-Valcarce, M., Vasickova, P., Kralik, P., Hernandez, M., Angeloni, G., et al. (2012). Hepatitis E virus in pork production chain in Czech Republic, Italy, and Spain, 2010. Emerging Infectious Diseases, 18(8), 1282-1289

Di Bartolo, I., Martelli, F., Inglese, N., Pourshaban, M., Caprioli, A., Ostanello, F., et al. (2008). Widespread diffusion of genotype 3 hepatitis E virus among farming swine in Northern Italy. Veterinary Microbiology, 132(1-2), 47-55

Diez-Valcarce, M., Kokkinos, P., Söderberg, K., Bouwknegt, M., Willems, K., de Roda Husman, A. M., et al. (2012). Occurrence of human enteric viruses in commercial mussels at retail level in three European countries. Food and Environmental Virology, 4(2), $73-80$

Diez-Valcarce, M., Kovač, K., Cook, N., Rodríguez-Lázaro, D., \& Hernández, M. (2011). Construction and analytical application of internal amplification controls (IAC) for detection of food supply chain-relevant viruses by real-time PCR-based assays. Food Analytical Methods, 4, 437-445

ECDC. (2017). European Centre for Disease Prevention and Control. Hepatitis E in the EU/EEA, 2005-2015. Stockholm. https://www. ecdc.europa.eu/en/publications-data/hepatitis-e-eueea-20052015\#no-link. Accessed on 5 Feb 2021

Feagins, A. R., Opriessnig, T., Guenette, D. K., Halbur, P. G., \& Meng, X.-J. (2007). Detection and characterization of infectious Hepatitis $\mathrm{E}$ virus from commercial pig livers sold in local grocery stores in the USA. Journal of General Virology, 88(Pt3), 912-917

Feurer, C., Le Roux, A., Rossel, R., Barnaud, E., Dumarest, M., Garry, P., et al. (2018). High load of hepatitis E viral RNA in pork livers but absence in pork muscle at French slaughterhouses. International Journal of Food Microbiology, 264, 25-30
Forgách, P., Nowotny, N., Erdélyi, K., Boncz, A., Zentai, J., Szucs, G., et al. (2010). Detection of hepatitis E virus in samples of animal origin collected in Hungary. Veterinary Microbiology, 143(2-4), $106-116$

García, N., Hernández, M., Gutierrez-Boada, M., Valero, A., Navarro, A., Muñoz-Chimeno, M., et al. (2020). Occurrence of hepatitis $\mathrm{E}$ virus in pigs and pork cuts and organs at the time of slaughter, Spain, 2017. Frontiers in Microbiology, 10, 2990

Geng, Y., Zhao, C., Guo, T., Xu, Y., Wang, X., Huang, W., et al. (2019). Detection of hepatitis $\mathrm{E}$ virus in raw pork and pig viscera as food in Hebei province of China. Foodborne Pathogens and Disease, 16(5), 325-330

Giannini, P., Jermini, M., Leggeri, L., Nüesch-Inderbinen, M., \& Stephan, R. (2018). Detection of hepatitis E virus RNA in raw cured sausages and raw cured sausages containing pig liver at retail stores in Switzerland. Journal of Food Protection, 81(1), 43-45

Grierson, S., Heaney, J., Cheney, T., Morgan, D., Wyllie, S., Powell, L., et al. (2015). Prevalence of hepatitis $E$ virus infection in pigs at the time of slaughter, United Kingdom, 2013. Emerging Infectious Diseases, 21(8), 1396-1401

Guillois, Y., Abravanel, F., Miura, T., Pavio, N., Vaillant, V., Lhomme, S., et al. (2016). High proportion of asymptomatic infections in an outbreak of hepatitis E associated with a spitroasted piglet, France, 2013. Clinical Infectious Diseases, 62(3), 351-357

Heldt, F. H., Staggmeier, R., Gularte, J. S., Demoliner, M., Henzel, A., \& Spilki, F. R. (2016). Hepatitis E virus in surface water, sediments, and pork products marketed in southern Brazil. Food and Environmental Virology, 8(3), 200-205

Hinjoy, S., Nelson, K. E., Gibbons, R. V., Jarman, R. G., Chinnawirotpisan, P., Fernandez, S., et al. (2013). A cross-sectional study of hepatitis $\mathrm{E}$ virus infection in pigs in different-sized farms in northern Thailand. Foodborne Pathogens and Disease, 10(8), 698-704

Hoan, N. X., Huy, P. X., Sy, B. T., Meyer, C. G., Son, T. V., Binh, M. T., et al. (2019). High hepatitis E virus (HEV) positivity among domestic pigs and risk of HEV infection of individuals occupationally exposed to pigs and pork meat in Hanoi, Vietnam. Open Forum Infectious Diseases, 6(9), ofz306

Horak, S., \& Leedom Larson, K.R. (2016). Porcine adenovirus. Swine Health Information Center and Center for Food Security and Public Health. http://www.cfsph.iastate.edu/pdf/shic-factsheet-porci ne-adenovirus. Accessed on 4 March 2021

Huang, F. F., Haqshenas, G., Guenette, D. K., Halbur, P. G., Schommer, S. K., Pierson, F. W., et al. (2002). Detection by reverse transcription-PCR and genetic characterization of field isolates of swine hepatitis $\mathrm{E}$ virus from pigs in different geographic regions of the United States. Journal of Clinical Microbiology, 40(4), $1326-1332$

ICSMF. (1986). International commission on microbiological specifications for foods (ICSMF): Microorganisms in foods 2. Sampling for microbiological analysis: Principles and specific applications. (2nd ed.). Blackwell Scientific Publications.

ICSMF. (2011). International commission on microbiological specifications for foods (ICSMF): Microorganisms in foods 8 . Springer Science+Business Media. https://doi.org/10.1007/ 978-1-4419-9374-8

Intharasongkroh, D., Sa-Nguanmoo, P., Tuanthap, S., Thongmee, T., Duang-in, A., Klinfueng, S., et al. (2016). Hepatitis E virus in pork and variety meats sold in fresh markets. Food and Environmental Virology, 9(1), 45-53

Jinshan, J., Manglai, D., Takahashi, M., Nagashima, S., \& Okamoto, H. (2010). Molecular and serological survey of hepatitis E virus infection among domestic pigs in Inner Mongolia, China. Archives of Virology, 155(8), 1217-1226

Jones, T. H., \& Muehlhauser, V. (2017). F-coliphages, porcine adenovirus and porcine teschovirus as potential indicator viruses of fecal 
contamination for pork carcass processing. International Journal of Food Microbiology, 241, 237-243

Kamar, N., Selves, J., Mansuy, J. M., Ouezzani, L., Peron, J. M., Guitard, J., et al. (2008). Hepatitis E virus and chronic hepatitis in organ-transplant recipients. The New England Journal of Medicine, 358(8), 811-817

King, N., Hewitt, J., \& Cressey, P. (2020). Transmission routes for hepatitis E virus infection in New Zealand with a particular focus on pig and deer products intended for human consumption. http:// www.mpi.govt.nz/news-and-resources/publications/. Accessed on 25 February 2021

Kokkinos, P., Kozyra, I., Lazic, S., Söderberg, K., Vasickova, P., Bouwknegt, M., et al. (2017). Virological quality of irrigation water in leafy green vegetables and berry fruits production chains. Food and Environmental Virology, 9(1), 72-78

Kozyra, I., Jabłoński, A., Bigoraj, E., \& Rzeżutka, A. (2020). Wild boar as a sylvatic reservoir of hepatitis E virus in Poland: A crosssectional population study. Viruses, 12(10), 111

Kubacki, J., Fraefel, C., Jermini, M., Giannini, P., Martinetti, G., Ripellino, P., et al. (2017). Complete genome sequences of two Swiss hepatitis $\mathrm{E}$ virus isolates from human stool and raw pork sausage. Genome Announcements, 5(35), e00888-e917

Lee, H. S., Dao, D. T., Bui, V. N., Bui, N. A., Le, T. D., Nguyen-Viet, H., et al. (2020). Prevalence and phylogenetic analysis of hepatitis E virus in pigs in Vietnam. BMC Veterinary Research, 16(1), 333

Li, W., She, R., Wei, H., Zhao, J., Wang, Y., Sun, Q., et al. (2009). Prevalence of hepatitis $\mathrm{E}$ virus in swine under different breeding environment and abattoir in Beijing, China. Veterinary Microbiology, 133(1-2), 75-83

Lowther, J. A., Henshilwood, K., \& Lees, D. N. (2008). Determination of norovirus contamination in oysters from two commercial harvesting areas over an extended period, using semiquantitative real-time reverse transcription PCR. Journal of Food Protection, 71(7), 1427-1433

Mansuy, J. M., Gallian, P., Dimeglio, C., Saune, K., Arnaud, C., Pelletier, B., et al. (2016). A nationwide survey of hepatitis E viral infection in French blood donors. Hepatology, 63(4), 1145-1154

Martínez-Martínez, M., Diez-Valcarce, M., Hernández, M., \& Rodríguez-Lázaro, D. (2011). Design and application of nucleic acid standards for quantitative detection of enteric viruses by real-time PCR. Food and Environmental Virology, 3(2), 92-98

Masuda, J.-I., Yano, K., Tamada, Y., Takii, Y., Ito, M., Omagari, K., et al. (2005). Acute hepatitis $\mathrm{E}$ of a man who consumed wild boar meat prior to the onset of illness in Nagasaki, Japan. Hepatology Research, 31(3), 178-183

Matsubayashi, K., Nagaoka, Y., Sakata, H., Sato, S., Fukai, K., Kato, T., et al. (2004). Transfusion-transmitted hepatitis E caused by apparently indigenous hepatitis E virus strain in Hokkaido, Japan. Transfusion, 44(6), 934-940

Matsuda, H., Okada, K., Takahashi, K., \& Mishiro, S. (2003). Severe hepatitis $\mathrm{E}$ virus infection after ingestion of uncooked liver from a wild boar. Journal of Infectious Diseases, 188(6), 944

Maunula, L., Kaupke, A., Vasickova, P., Söderberg, K., Kozyra, I., Lazic, S., et al. (2013). Tracing enteric viruses in the European berry fruit supply chain. International Journal of Food Microbiology, 167(2), 177-185

Meng, X. J., Purcell, R. H., Halbur, P. G., Lehman, J. R., Webb, D. M., Tsareva, T. S., et al. (1997). A novel virus in swine is closely related to the human hepatitis E virus. Proceedings of the National Academy of Sciences of the United States of America, 94(18), 9860-9865

Milojević, L., Velebit, B., Teodorović, V., Kirbiš, A., Petrović, T., Karabasil, N., et al. (2019). Screening and molecular characterization of hepatitis E virus in slaughter pigs in Serbia. Food and Environmental Virology, 11(4), 410-419
Mitsui, T., Tsukamoto, Y., Yamazaki, C., Masuko, K., Tsuda, F., Takahashi, M., et al. (2004). Prevalence of hepatitis E virus infection among hemodialysis patients in Japan: Evidence for infection with a genotype $3 \mathrm{HEV}$ by blood transfusion. Journal of Medical Virology, 74(4), 563-572

Miyashita, K., Kang, J.-H., Saga, A., Takahashi, K., Shimamura, T., Yasumoto, A., et al. (2012). Three cases of acute or fulminant hepatitis E caused by ingestion of pork meat and entrails in Hokkaido, Japan: Zoonotic food-borne transmission of hepatitis $\mathrm{E}$ virus and public health concerns. Hepatology Research, 42(9), 870-878

Mokhtari, C., Marchadier, E., Haïm-Boukobza, S., Jeblaoui, A., Tessé, S., Savary, J., et al. (2013). Comparison of real-time RT-PCR assays for hepatitis E virus RNA detection. Journal of Clinical Virology, 58(1), 36-40

Mykytczuk, O., Harlow, J., Bidawid, S., Corneau, N., \& Nasheri, N. (2017). Prevalence and molecular characterization of the hepatitis E virus in retail pork products marketed in Canada. Food and Environmental Virology, 9(2), 208-218

Paszkiewicz, W., Kozyra, I., Bigoraj, E., Ziomek, M., \& Rzeżutka, A. (2016). A molecular survey of farmed and edible snails for the presence of human enteric viruses: Tracking of the possible environmental sources of microbial mollusc contamination. Food Control, 69, 368-372

Pavio, N., Merbah, T., \& Thébault, A. (2014). Frequent hepatitis E virus contamination in food containing raw pork liver, France. Emerging Infectious Diseases, 20(11), 1925-1927

Pełczyńska, E., \& Libelt, K. (1999). The biological value of slaughter animals blood. Medycyna Weterynaryjna, 55(9), 600-601

Pérez-Gracia, M. T., García, M., Suay, B., \& Mateos-Lindemann, M. L. (2015). Current knowledge on hepatitis E. Journal of Clinical and Translational Hepatology, 3(2), 117-126

Polish Standard (1964). PN-A-85701: Blood of slaughter animals and derived (Krew zwierzat rzeźnych i jej pochodne). Polish Committee for Standardization.

Polish Standard (1965). PN-A-82000: Meat and offal of slaughter animals - Common requirements and research (Mięso i podroby zwierzat rzeźnych -Wspólne wymagania i badania). Polish Committee for Standardization.

Polish Standard (1986). PN-A-82004: Offal of slaughter animals (Podroby zwierzat rzeźnych). Polish Committee for Standardization.

Regulation (EC) No 853/2004 of the European Parliament and of the Council of 29 April 2004-Laying down specific hygiene rules for food of animal origin. O.J. L 139, 30.04.2004., p. 55. http:// data.europa.eu/eli/reg/2004/853/oj. Accessed on 15 May 2020

Renou, C., Roque-Alfonso, A., \& Pavio, N. (2014). Foodborne transmission of HEV from raw pork liver sausage in France. Emerging Infectious Diseases, 20(11), 1945-1947

Rutjes, S. A., Bouwknegt, M., van der Giessen, J. W., de Roda Husman, A. M., \& Reusken, C. B. (2014). Seroprevalence of hepatitis $\mathrm{E}$ virus in pigs from different farming systems in The Netherlands. Journal of Food Protection, 77(4), 640-642

Rzeżutka, A., \& Carducci, A. (2013). Sampling strategies for virus detection in foods, food processing environments, water and air. In: Cook N. (Ed.), Viruses in food and water: Risks, surveillance and control. (pp. 79-96). Woodhead Publishing.

Rzeżutka, A., Chrobocińska, M., Kaupke, A., \& Mizak, B. (2008). Application of an ultracentrifugation-based method for detection of feline calicivirus (a norovirus surrogate) in experimentally contaminated delicatessen meat samples. Food Analytical Methods, 1, 56-60

Satake, M., Matsubayashi, K., Hoshi, Y., Taira, R., Furui, Y., Kokudo, N., et al. (2017). Unique clinical courses of transfusion-transmitted hepatitis $\mathrm{E}$ in patients with immunosuppression. Transfusion, 57(2), 280-288

Schemmerer, M., Johne, R., Erl, M., Jilg, W., \& Wenzel, J. J. (2019). Isolation of subtype $3 \mathrm{c}, 3 \mathrm{e}$ and $3 \mathrm{f}$-like hepatitis $\mathrm{E}$ virus strains 
stably replicating to high viral loads in an optimized cell culture system. Viruses, 11(6), 483

Smith, D. B., Izopet, J., Nicot, F., Simmonds, P., Jameel, S., Meng, X.-J., et al. (2020). Update: Proposed reference sequences for subtypes of hepatitis E virus (species Orthohepevirus A). Journal General Virology. https://doi.org/10.1099/jgv.0.001435

Smith, D. B., Simmonds, P., International Committee on Taxonomy of Viruses Hepeviridae Study Group, Jameel, S., Emerson, S. U., Harrison, T. J., et al. (2014). Consensus proposals for classification of the family Hepeviridae. Journal of General Virology, 95(Pt 10), 2223-2232

Sooryanarain, H., Heffron, C. L., Hill, D. E., Fredericks, J., Rosenthal, B. M., Were, S. R., et al. (2020). Hepatitis E virus in pigs from slaughterhouses, United States, 2017-2019. Emerging Infectious Diseases, 26(2), 354-357

Szabo, K., Trojnar, E., Anheyer-Behmenburg, H., Binder, A., Schotte, U., Ellerbroek, L., et al. (2015). Detection of hepatitis E virus RNA in raw sausages and liver sausages from retail in Germany using an optimized method. International Journal of Food Microbiology, 215, 149-156

Takahashi, H., Tanaka, T., Jirintai, S., Nagashima, S., Takahashi, M., Nishizawa, T., et al. (2012). A549 and PLC/PRF/5 cells can support the efficient propagation of swine and wild boar hepatitis $\mathrm{E}$ virus (HEV) strains: Demonstration of HEV infectivity of porcine liver sold as food. Archives of Virology, 157(2), 235-246

Tamada, Y., Yano, K., Yatsuhashi, H., Inoue, O., Mawatari, F., \& Ishibashi, H. (2004). Consumption of wild boar linked to cases of hepatitis E. Journal of Hepatology, 40(5), 869-870

Tei, S., Kitajima, N., Takahashi, K., \& Mishiro, S. (2003). Zoonotic transmission of hepatitis $\mathrm{E}$ virus from deer to human beings. Lancet, 362(9381), 371-373

Temmam, S., Besnard, L., Andriamandimby, S. F., Foray, C., Rasamoelina-Andriamanivo, H., Héraud, J.-M., et al. (2013). High prevalence of hepatitis $\mathrm{E}$ in humans and pigs and evidence of genotype-3 virus in swine, Madagascar. American Journal of Tropical Medicine and Hygiene, 88(2), 329-338

Thiry, D., Mauroy, A., Saegerman, C., Thomas, I., Wautier, M., Miry, C., et al. (2014). Estimation of hepatitis E virus (HEV) pig seroprevalence using ELISA and Western blot and comparison between human and pig HEV sequences in Belgium. Veterinary Microbiology, 172(3-4), 407-414
Walachowski, S., Dorenlor, V., Lefevre, J., Lunazzi, A., Eono, F., Merbah, T., et al. (2014). Risk factors associated with the presence of hepatitis $\mathrm{E}$ virus in livers and seroprevalence in slaughter-age pigs: a retrospective study of 90 swine farms in France. Epidemiology and Infection, 142(9), 1934-1944

WHO. (2019). World Health Organization - Hepatitis E virus. Retrieved 8 July 2019 from https://www.who.int/news-room/ fact-sheets/detail/hepatitis-e

WHO. (2020). World Health Organization - Hepatitis E. Retrieved 27 July 2020 from https://www.who.int/news-room/fact-sheets/detail/ hepatitis-e

Wilhelm, B., Leblanc, D., Houde, A., Brassard, J., Gagné, M.-J., Plante, D., et al. (2014). Survey of Canadian retail pork chops and pork livers for detection of hepatitis E virus, norovirus, and rotavirus using real time RT-PCR. International Journal of Food Microbiology, 185, 33-40

Wu, J. C., Chen, C. M., Chiang, T. Y., Tsai, W. H., Jeng, W. J., Sheen, I. J., et al. (2002). Spread of hepatitis E virus among different-aged pigs: Two-year survey in Taiwan. Journal of Medical Virology, 66(4), 488-492

Wyn-Jones, A. P., Carducci, A., Cook, N., D’Agostino, M., Divizia, M., Fleischer, J., et al. (2011). Surveillance of adenoviruses and noroviruses in European recreational waters. Water Research, 45(3), 1025-1038

Yapa, C. M., Furlong, C., Rosewell, A., Ward, K. A., Adamson, S., Shadbolt, C., et al. (2016). First reported outbreak of locally acquired hepatitis E virus infection in Australia. Medical Journal of Australia, 204(7), 274

Yazaki, Y., Mizuo, H., Takahashi, M., Nishizawa, T., Sasaki, N., Gotanda, Y., et al. (2003). Sporadic acute or fulminant hepatitis $\mathrm{E}$ in Hokkaido, Japan, may be food-borne, as suggested by the presence of hepatitis E virus in pig liver as food. Journal of General Virology, 84(Pt9), 2351-2357

Yugo, D. M., \& Meng, X. J. (2013). Hepatitis E virus: Foodborne, waterborne and zoonotic transmission. International Journal of Environmental Research and Public Health, 10(10), 4507-4533

Publisher's Note Springer Nature remains neutral with regard to jurisdictional claims in published maps and institutional affiliations. 